\title{
REAL ESTATE INVESTMENT DECISIONS II: COMMERCIAL OFFICE PROPERTY LEASING
}

\author{
Jonathan Breazeale \\ Sam Houston State University • Huntsville, TX
}

\section{ABSTRACT}

You are an asset manager of City View Office, a publicly traded Real Estate Investment Trust (REIT) with a portfolio of commercial office properties. Your leasing agent has just brought you a request for proposal (RFP) from a potential creditworthy tenant who wants to lease office space in your Class A property. Your task is to determine whether or not your firm - the landlord - should enter into the lease.

\section{REAL ESTATE INVESTMENT TRUSTS (REITS)}

To avoid corporate income taxes, REITs pay out at least $90 \%$ of their otherwise taxable earnings to their shareholders. Historically, and due to these high dividend payouts, REITs have been considered an investment vehicle of "widows and orphans," but they really are designed to provide a way for small "retail" investors to access a very capital intensive sector of the economy in which they would otherwise be prohibited from participating. Note that the main requirement for REIT status (the $90 \%$ payout rule) is an accounting requirement - as are most of the requirements for REIT status. As long as REITs meet these accounting requirements, their earnings are not taxed at the corporate level. Instead, REIT profits are taxed only at the personal level via taxes on dividends and capital gains. Investors get to "have their cake and eat it too." They receive both the limited liability offered by corporations and single (or pass-through) taxation. The operation of a REIT, however, is very much the same as any other real estate firm. Investment decisions are made in much the same way. Financing decisions, however, can be a bit different because debt no longer offers a tax shield from interest payments.

Office REITs - like other non-REIT office property owners - purchase single and multi-tenant office properties. Like all real estate owners, they generate a return for their shareholders by purchasing a property and selling it in the future at a higher price. Not only do REITs recognize the capital gain from the purchase and sale, they also receive the cash flows generated by the operation of the property. In other words, the success or failure of the leasing effort has an impact on all three types of cash flows - purchase price, sales price, and operating cash flows during ownership. If the building is purchased at $100 \%$ occupancy with high rental rates, the purchase 
price will be high. If the building is sold at $50 \%$ occupancy with low rates, the seller will not receive what they otherwise could. The cash flows received during the years of ownership are similarly influenced by leasing. Commercial office property owners are subject to the same old adage - maximize revenues and minimize costs.

\section{LEASING}

Leasing is to landlords as sales are to industrial firms. It is their life's blood - their revenue stream. The typical office lease involves a variety of marginal cash flows to consider in determining whether of not the proposed deal is a good one for the landlord. Of course, every detail of an office lease is negotiable but the basics are relatively uniform.

First, the landlord agrees to incur some capital expenditures (Cap Ex) in order to pay the brokers (both the tenant's and the landlord's) and create the office space that suits the tenant's needs. Brokers' commissions are always negotiable but local market rates do tend to prevail. In other words, the commissions that landlords pay in Atlanta will not be the same as the commissions landlords expect to pay in Houston. The amount needed to configure the space for the tenant is called tenant improvements (TI) or the work letter. The cost of the work letter depends on two things: (1) the condition of the existing space relative to the layout that fits the tenant's needs, and (2) the tenant's "taste" for upgraded finishes - plush carpet, granite countertops, stained base boards and moldings, etc. The layout of walls, doors, electrical outlets, etc., is a relatively easy thing to change in an office building, but it can be quite expensive. As a general rule, the more capital required to reconfigure the space to suit the tenant's needs, the higher the rent. In some instances (in tenant-friendly markets), the landlord might also offer a moving allowance or some other Cap Ex incentive to move into the property. For long-term leases, landlords may also have to offer the tenant a refresher allowance of some type in the middle of the term to paint and/or freshen up the space due to the long lease term. As with all aspects of a lease, supply and demand for office space will dictate how much of an allowance the landlord must provide and how much of the construction the tenant must pay for themselves.

Next, the tenant most often agrees (especially on a new deal) to produce a security deposit to reduce the probability that they will default on the terms of the lease. The landlord has put money at risk to pay the brokers and configure the space, so the security deposit reduces the tenant's incentive to pay rent late or move out of the space in the middle of the night and default on their obligations. Alternative security exists in either a letter of credit or a personal guarantee. A letter of credit 
is a letter from a bank stating that in the event that the tenant fails to pay rent or otherwise defaults on the lease, the landlord can present the letter of credit to the bank for payment in the amount listed in the letter. Effectively, the bank is insuring all - or a portion of - the rent. A personal guarantee is a document that makes an individual personally liable for the rent in the event of corporate default. In the case of a personal guarantee, landlords analyze the credit worthiness of both the corporate entity signing the lease and the individual net worth of the guarantor in the form of personal financial statements and income tax returns.

Lastly, it is not uncommon for landlords to check credit by checking public records and interviewing previous landlords. Typically the Office of the Comptroller of the Currency (OCC) will release whether a company is delinquent in the payment of their franchise taxes. If the company is delinquent on taxes due in the state in which they are incorporated, then it's more likely that they'll be delinquent on their rent as well. A conversation with previous landlord(s) will also reveal whether the tenant has been habitually late on their rent payments or was otherwise a difficult occupant in a multi-tenant environment. If a tenant passes muster on each of these security measures and still defaults on its rent, then the final remedy available to landlords is to lock the space and exercise its lien on the assets therein. Remember, a lease is a liability on the tenant's balance sheet and landlords have a claim on the tenants' assets just as a bank or bondholder would.

The tenant pays rent on a monthly basis. Rent is due by the 1 st of the month, and it is usually considered late if not received by the 5 th. A late fee of $5 \%$ of the overdue amount plus interest is customary if rent is not received on time. While these late charges are substantial and often collected, they are not typically modeled in the lease valuation process. Landlords do not expect late fees. Failure to pay rent usually results in a relatively aggressive collections effort on the part of the landlord. A phone call or meeting with the tenant happens on the 6th of the month as this is a pretty large red flag. Landlords provide electricity to the space, janitorial services, elevator maintenance, heating and cooling, and pay ad valorem taxes on time, and they expect tenants to pay rent on time as well.

Office rent in most markets is referred to as gross rent. This means that the operating expenses of the property are to be paid by the landlord. Landlord operating expenses include contracted services (such as janitorial and security), repairs and maintenance, utilities, personnel expenses, management fees, office and administrative, insurance, ad valorem taxes, and other non-pass through items such as advertising and legal fees. After the first calendar year (specified within the lease as the "Base Year"), tenants pay for any proportional increases in the allowable pass- 
through expenses. This protects the landlord from the costs of inflation; however, landlords of multitenant office buildings always have an incentive to keep costs down since a percentage of their property will be expiring each year.

Here's an example of how operating expenses on a gross lease work: Suppose a tenant commences a 10,000 square foot (SF) new lease on October 1, 2018, in a 100,000 square foot building. Most likely, the Base Year established within the lease document will be 2019. For the period October 1, 2018 to December 31, 2019, the tenant will simply pay Base Rent on a monthly basis. If the actual reimbursable (pass-through) operating expenses for the property for the calendar year 2019 are $\$ 10.00$ per SF, then the tenant will be responsible for their pro-rata share of any increases in operating expenses over and above $\$ 10.00$ per SF for the duration of their lease. So if pass-through expenses in 2020 are projected to be $\$ 10.50$ per SF, then beginning January 1,2020 , the tenant will also pay $10 \%$ (their pro-rata share: $10,000 \mathrm{SF} / 100,000 \mathrm{SF}$ ) of the expected increase in operating expenses. For a $100,000 \mathrm{SF}$ property, the $\$ 0.50$ increase in expenses per foot for the 10,000 SF suite is $\$ 50,000$, and $10 \%$ of that amount is $\$ 5,000$. On a monthly basis, that is $\$ 416.67$ in Additional Rent that is due the landlord beginning January 1, 2020. By around March of 2021, the landlord will have completed an actual accounting of the building's operating expenses for 2011 and will reconcile the estimated \$5,000 Additional Rent with the actual expenses and either bill the tenant for any 2020 overage or refund any 2020 overpayment.

Alternatively, in lieu of establishing a Base Year, some leases establish a Base Stop whereby the level of operating expenses that are the landlord's responsibilities are expressly established. In the previous example, the lease may already establish the landlord's responsibility at $\$ 10.00$ per SF without regard to the calendar year in which it occurs. In this case, the tenant will always be responsible for any pro-rata increases in operating expenses of the property in excess of $\$ 10.00$ per SF.

As if this arrangement for operating expenses wasn't complex enough already, two more items are sometimes included in the pass-through discussion of an office lease. First, tenants will often negotiate an annual cap on percentage increases in operating expenses each year. In other words, they will not pay any increases in excess of $4 \%$ of last year's actual expenses. This protects the tenant from unseen increases in property taxes, utilities, insurance, etc. and further incentivizes the landlord to do everything in their power to keep costs low. Second, the operating expense discussion will allow for a Gross Up of operating expenses to a specified level of occupancy. For example, the lease will state that if in any year of the lease that the property does not have an average occupancy of, say, $90 \%$, then the operating expenses for that year will be adjusted to the level of operating expenses that would have occurred had the property been at $90 \%$ occupancy. Sound crazy? Well, it is. Office REITs and non-REIT office owners typically employ many accountants! 


\section{THE TENANT}

Senior Sta-Home, Inc. (SSH) has been in business in the Houston area for over 15 years. They provide home health care and rehabilitation for geriatric patients throughout the city. They've been leasing space since the company's inception in the Greenway Plaza submarket in a Class B building, and they'd like to take advantage of the depressed office market to upgrade to nicer space for less money. Any press that you've seen on SSH has been positive albeit very spotty. Their existing landlord refuses to talk to you about their history because they want SSH to stay where they are and renew their existing lease. As a result, you don't really know if SSH is serious about their search or if their broker is just trying to provide a few more data points for his client as ammunition to renew their existing lease at a much more favorable rate. They aren't asking for any more space than they already lease, but you don't know how well the layout of the existing space meets their operational needs. Perhaps they just need a new floor plan.

Regardless of how serious SSH is about their search for office space, times are tough. You want to turn your non-income earning vacancy into rent producing square footage. Your CEO has been on a tear to increase occupancy in this tough leasing environment by making more competitive offers than comparable properties. SSH has provided you with their unaudited financial statements (Exhibit 1).

\section{THE DEAL}

The deal you've just been brought is for a property located in the Westchase corridor of Houston, Texas. Your broker, to whom you pay a $2 \%$ commission on the day the tenant moves into the space, has presented a deal with SSH who is looking to relocate its 6,500 to 7,000 square foot office to the west side of town. The tenant's broker is asking for a $4 \%$ commission to put his client into your building. The last three leases that you signed at the property were at rental rates of $\$ 16, \$ 16.50$ and $\$ 16.25$ per square foot per year, but they are asking for a much lower rate than that. Annual operating expenses at the property are $\$ 10.00$ per square foot, and $\$ 4.00$ of that are fixed costs. The tenant is asking for a turnkey work letter (where you agree to pay whatever cost needed to construct the space per mutually agreeable construction documents (CDs)), but you are hesitant to grant such a liberal request. Your architect figures that you can meet their needs with an Improvement Allowance of about $\$ 10$ per SF, which is expected to take two months to complete. 
You would certainly like to try to push rates to $\$ 16.75$ per SF - although it's a very tough market. City View's cost of capital is currently 9.0\%. Your largest concern is that the tenant wants nine months of free rent on the front end of the lease on a five-year deal! This is way beyond what you believe the market for free rent to be (about one month of free rent for each year of the lease). The tenant does not require any signage or roof access for an antenna, so you don't expect any additional revenue other than rent. The current market will not allow you to charge for parking. You will base security deposit requirements on your review of their financials and underwriting. The actual Request for Proposal (RFP) is provided in Exhibit 2.

In essence, SSH has asked for the moon. You're not sure that you can accommodate every one of their requests. The only thing that you know for sure is that you are sick of the weak office market. When will you stop seeing such unfavorable conditions for landlords?

\section{Exhibit 1. \\ Tenant's Submitted Financial Statements \\ Senior Sta-Home, Inc. \\ Consolidated Balance Sheet as of December 31, 2017 \\ Unaudited - Internally Prepared \\ Modified Cash Basis}

\section{Assets}

Current Assets

Checking / Savings-Cash In Bank

$\$ \quad 1,000,073$

Accounts Receivable

Associated Practices (net of allow. for uncollectable)

$\$ \quad 10,350$

Therapy Fees (net of allow. for uncollectable)

Total Accounts Receivable

\begin{tabular}{rr} 
& $1,654,285$ \\
\hline$\$ \quad 1,664,635$ \\
\hline
\end{tabular}

Other Current Assets

Employee Load

$\$ \quad 4,249$

Petty Cash

8,627

Total Other Current Assets

Total Current Assets

\begin{tabular}{lr} 
& 8,627 \\
\hline$\$$ & 12,877 \\
\hline$\$$ & $2,677,585$
\end{tabular}

Fixed Assets

Office Equipment and Furniture 
Investment in Affiliate

Organization Cost \& Amortization

Prepaid Expenses \& Security Deposits

Total Other Assets

TOTAL ASSETS
$\$ 340$

423

\begin{tabular}{lr} 
& 7,203 \\
\hline$\$$ & 7,966 \\
\hline$\$$ & $2,690,066$ \\
\hline
\end{tabular}

\section{Liabilities \& Equity}

Current Liabilities

Accounts Payable

$\$ \quad 167,288$

Other Current Liabilities

401K ER Contribution

$\$ \quad 67,190$

Other Payables

$\$ \quad 247,500$

Total Other Current Liabilities

\$ 314,690

Total Current Liabilities

$\$ \quad 481,977$

Other Liability: Overpayment Reserve

Equity

Common Stock - Class A\&B

$\$ \quad 4,000$

Retained Earnings

$1,812,303$

Treasury Stock

$(250,000)$

Total Equity

$\$ \quad 1,566,303$

TOTAL LIABILITIES \& EQUITY

$\$ 2,690,066$ 
Senior Sta-Home, Inc.

Consolidated Profit and Loss

For the Period Ending December 31, 2017

Unaudited - Internally Prepared

Modified Cash Basis

\section{Jan-Dec 2017}

Ordinary Income/Expense

Income

Associate Fees

$\$ 779,768$

Therapy Fees

\begin{tabular}{rr}
$12,757,118$ \\
\hline$\$ \quad 13,536,886$ \\
\hline
\end{tabular}

Total Income

Expense

Advertising

$\$$

4,069

Amortization Expense

594

Bank Fees

Billing Cost

686,871

Business Meals \& Entertainment

14,538

Computer Expenses

27,208

Consulting

75,042

Contributions

1,600

Depreciation

2,464

Dues and Subscriptions

7,133

Employee Benefits

23,863

Equipment Rental

6,000

Facility Expense

104,881

Insurance

425,123

Legal and Accounting

16,949

Licenses

Marketing

19,146

Office Expense

99,352

Postage/Delivery

Professional Development

Recruiting Expense

Rent 
Repairs and Maintenance

13,504

Research \& Development

38,905

Salaries and Wages

$5,652,007$

Payroll Expense

494,701

Tax-Property \& Franchise

Telephone

52,716

Training

2,776

Travel

121,902

Uncollectable Accounts

36,063

Total Expense

Net Ordinary Income

\begin{tabular}{cr}
$\$$ & $8,127,802$ \\
\hline$\$$ & $5,409,084$
\end{tabular}

Other Income / Expenses

Other Income

17,986

Other Expenses

Agent Fees

160,000

ER 401K Contributions

67,190

Federal Income Tax

3,000

Managed Unit Compensation

$1,606,646$

Management Base Compensation

650,316

Total Other Expense

Net Other Income (Expense)

$\$ 2,487,152$

$\$(2,469,166)$

Net Income Before Management Bonus

$\$ 2,939,918$

Management Bonus

$3,117,593$

Net Income (Loss)

\begin{tabular}{rr}
$3,117,593$ \\
\hline$\$ \quad(117,675)$ \\
\hline
\end{tabular}


Exhibit 2.

Tenant's Request For Proposal (RFP)

\begin{tabular}{|c|c|c|}
\hline \multicolumn{3}{|c|}{$\begin{array}{l}\text { Tenant Brokerage Services } \\
780 \text { North Avenue } \\
\text { Houston, TX } 77098\end{array}$} \\
\hline October 22, 2018 & \multirow{2}{*}{\multicolumn{2}{|c|}{ Via email: leasing.agent@landlord.com }} \\
\hline $\begin{array}{l}\text { Mrs. Leasing Agent } \\
\text { Landlord Realty Services } \\
123 \text { Main Street } \\
\text { Houston, TX } 77098\end{array}$ & & \\
\hline \multicolumn{3}{|c|}{ RE: Proposal for Senior Sta-Home, Inc. / 358 West Street } \\
\hline \multicolumn{3}{|l|}{ Dear Mrs. Agent: } \\
\hline \multicolumn{3}{|c|}{$\begin{array}{l}\text { As exclusive agent for Senior Sta-Home, Inc. ("Tenant"), we are forwarding this Proposal } \\
\text { for their potential office lease at the } 358 \text { West Street office building ("Building"). }\end{array}$} \\
\hline Premises: & \multicolumn{2}{|c|}{ Approximately 6,500 to 7,000 square feet on the 5 th floor } \\
\hline Term: & \multicolumn{2}{|l|}{69 Months } \\
\hline Lease Commencement: & \multicolumn{2}{|c|}{ January 1, 2019} \\
\hline Expiration Date: & \multicolumn{2}{|c|}{ September 30, 2022} \\
\hline Base Rental Rate: & $\begin{array}{l}\text { Months 1-9: } \\
\text { Months 10-44: }\end{array}$ & $\begin{array}{l}\$ 0.00 \text { per SF/Year } \\
\$ 14.25 \text { per SF/Year }\end{array}$ \\
\hline Operating Expenses: & \multicolumn{2}{|c|}{$\begin{array}{l}\text { Tenant will be responsible for all increases above and } \\
\text { beyond the actual operating expenses for the calendar year } \\
2019 \text { ("Base Year 2019"), with such expenses being grossed } \\
\text { up to reflect a 100\% occupancy for the Building. Operating } \\
\text { expense escalations will be capped at an annual increase of } \\
\text { no more than five percent (5\%). }\end{array}$} \\
\hline Tenant Improvements: & \multicolumn{2}{|c|}{$\begin{array}{l}\text { Landlord will provide a "turn-key" Improvement Allowance, } \\
\text { based on architectural plans to be mutually agreed to by } \\
\text { Landlord and Tenant with building standard finishes. }\end{array}$} \\
\hline
\end{tabular}


Option to Renew:

Right of First Refusal:

Parking:

Broker:
The lease shall contain one (1) five (5) year option to renew the lease for the demised Premises, upon providing the Landlord with six (6) months prior written notice. The Base Rental Rate shall be ninety-five percent (95\%) of the Fair Market Rental Rate at the time Tenant exercises this option. Landlord will have twenty (20) days to provide Tenant with their interpretation of prevailing market rate terms. In the event that Tenant does not agree to Landlord's proposal, then during the thirty (30) days following the delivery of Landlord's proposal, Tenant and Landlord will both use reasonable and diligent efforts to arrive at mutually agreeable terms. In the event that agreeable terms are not reached, then Tenant may rescind its notice to exercise its renewal option, and the renewal option will then become void.

Tenant shall have an ongoing Right of First Refusal (ROFR) for adjacent vacant space at the Fair Market Rental Rate, with such right to be based upon bona fide offers and include a 5 business day notice period and subject to any existing Tenant's rights currently in place, to be defined specifically in the Lease.

Landlord will provide Tenant 33 covered parking spaces (5 of which will be reserved) at no charge throughout the Lease Term.

Landlord agrees to pay Tenant's designated broker, Tenant Realty, a commission equal to four percent (4\%) of the total Gross Base Rental received of the lease term, payable upon lease signature per a separate agreement.

This Proposal is submitted subject to the review and mutual acceptance of the final terms and conditions to be contained in the lease amendment. Nothing contained herein shall be binding upon either party unless and until such documents have been fully executed and exchanged by both parties.

Thank you for your prompt response and if you have any questions, please give us a call at your earliest convenience.

Regards,

Tenant Broker 


\section{INSTRUCTORS' NOTES}

\section{Case Description}

The primary subject matter of this case concerns a landlord's financial analysis of an office lease. Secondary issues include the quintessential aspects of office REITs. Students are not usually familiar with REITs - especially those at the undergraduate level. The case has a difficulty level of three, appropriate for undergraduate juniors or seniors, and the case can be taught in a single 80 minute class period. Alternatively, the case can be used as a problem in a course on spreadsheet modeling.

\section{Case Synopsis}

You are an Asset Manager for a commercial office Real Estate Investment Trust (REIT). Your leasing agent has just brought a Request for Proposal (RFP) from a local business needing space better suited to their operations and their recent growth. It is the fourth quarter of 2018, and the new tenant wants to move in as soon as construction is complete on the space - as quickly as possible. You want to lease the space at a rental rate that increases the value of the property, but you don't want to run the prospective tenant off to a competitor.

\section{REAL ESTATE CONCEPTS}

This case covers issues related to leasing decisions by Real Estate Investment Trusts (REITs). This conceptual information is not necessarily pertinent to the calculations required to make decisions about the lease in question, but rather to expose students to an industry they might not otherwise be exposed to in a typical course in financial decision-making. REITs (both public and private) are a driving force in the market for commercial real estate, and they own many of the properties that other types of businesses lease space from to conduct their operations. In other words, students stand a good chance of a REIT being their commercial landlord. A sister paper to this case is Breazeale (2017) titled "Real Estate Investment Decisions I: Commercial Office Property Acquisitions." That paper leads students through the much more difficult decisions associated with property acquisitions by REITs (and other real estate owners). This case completes the total picture associated with how real estate firms add value for their shareholders through real estate investment decisions. 
The prospective tenant is fictitious and not intended to reflect any particular actual firm. Any resemblance to an actual firm is purely incidental - although the tenant in question is typical of a private firm in the market for office space. Of particular importance in the case are (1) identifying the pertinent marginal cash flows relevant to value creation for the real estate owner, (2) determining the credit worthiness of the tenant and required security (if any) - despite unaudited and tenantprovided financial statements, and (3) determining an appropriate offer in response to the Request for Proposal (RFP).

\section{SUGGESTED QUESTIONS FOR STUDENTS}

The following questions are provided to aid in discussion and help determine a solution. The list is not exhaustive, and students may bring forth points not listed here. 1. Should you respond to the RFP? Does their request add any value for the landlord?

Answer: The following table provides an NPV calculation for the tenant's RFP. While the NPV is positive and adds value for the landlord, the tenant's request for a turnkey work letter poses the greatest financial risk to the proposal. The proposed solution incorporates $\$ 10.00$ per square foot to reconfigure the space, but the term "turnkey" effectively means that the landlord is agreeing to pay whatever it takes to provide the space the tenant wants. This is never a good idea for the landlord. If the work totals $\$ 11.00$ per square foot, the deal no longer creates value. A good proposal should cap the landlords financial responsibility for the initial construction to a specified amount to avoid the risk of destroying value.

While the tenant broker has asked for a $4.0 \%$ commission, it will take $2.0 \%$ more to pay your leasing representative. Total leasing commissions are therefore assumed to be $6.0 \%$ of the total rent generated by the lease.

Notice that the time value of money associated with a security deposit is also included. If students require a letter of credit or personal guarantee, those measures of security would not be included since they are not cash items.

The applicable operating expenses for financial evaluation are the variable portion of the operating expenses. Fixed operating expenses for the leased space are incurred by the landlord regardless of whether or not the space is leased. Since the balance of the floor is probably leased, heating and cooling costs aren't marginal. Repairs and maintenance to elevators, lobbies and common areas would not be included either. Janitorial costs to clean the space nightly would certainly be included as marginal. Ad Valorem taxes also 
increase with the earnings of the property. $\$ 6.00$ per square foot is a good approximation of the variable costs for the space ( $\$ 6.00$ per foot $* 6,500$ feet $/ 12$ months $=\$ 3,250$ per month).

Finally, the following analysis assumes a $9.0 \%$ weighted-average cost of capital (WACC). Students may very well assume something different. Nine-percent may be a bit high, but whatever number they use should be substantiated by returns offered on similar properties in the same submarket.

Senior Sta-Home, Inc.

$\begin{aligned} \$ 14.25 & \text { Gross Rental Rate on a per Square Foot per Year Basis } \\ 6,500 & \text { Square Footage of the Office Suite } \\ 6.00 \% & \text { Leasing Commissions as a Percentage of Total Gross Rent (LCs) } \\ \$ 10.00 & \text { Tenant Improvements per Square Foot of Space (TI) } \\ \$ 10.00 & \text { Total Operating Expenses per Square Foot of Space (OpEx) } \\ \$ 4.00 & \text { Fixed Operating Expenses per Square Foot of Space } \\ 9.00 \% & \text { WACC }\end{aligned}$

\begin{tabular}{|c|c|c|c|c|c|c|c|}
\hline Month & Date & $\mathrm{Ti}$ & LCs & Deposit & Rent & Op Ex & Net CFs \\
\hline 0 & $1 / 1 / 13$ & $(65,000)$ & $(16,673)$ & $15,437.50$ & - & $(3,250)$ & $(69,485)$ \\
\hline 1 & $2 / 1 / 13$ & & & & - & $(3,250)$ & $(3,250)$ \\
\hline 2 & $3 / 1 / 13$ & & & & - & $(3,250)$ & $(3,250)$ \\
\hline 3 & $4 / 1 / 13$ & & & & - & $(3,250)$ & $(3,250)$ \\
\hline 4 & $5 / 1 / 13$ & & & & - & $(3,250)$ & $(3,250)$ \\
\hline 5 & $6 / 1 / 13$ & & & & - & $(3,250)$ & $(3,250)$ \\
\hline 6 & $7 / 1 / 13$ & & & & - & $(3,250)$ & $(3,250)$ \\
\hline 7 & $8 / 1 / 13$ & & & & - & $(3,250)$ & $(3,250)$ \\
\hline 8 & $9 / 1 / 13$ & & & & - & $(3,250)$ & $(3,250)$ \\
\hline 9 & $10 / 1 / 13$ & & & & $7,718.75$ & $(3,250)$ & $4,468.75$ \\
\hline 10 & $11 / 1 / 13$ & & & & $7,718.75$ & $(3,250)$ & $4,468.75$ \\
\hline 11 & $12 / 1 / 13$ & & & & $7,718.75$ & $(3,250)$ & $4,468.75$ \\
\hline 12 & $1 / 1 / 14$ & & & & $7,718.75$ & $(3,250)$ & $4,468.75$ \\
\hline 13 & $2 / 1 / 14$ & & & & $7,718.75$ & $(3,250)$ & $4,468.75$ \\
\hline 14 & $3 / 1 / 14$ & & & & $7,718.75$ & $(3,250)$ & $4,468.75$ \\
\hline
\end{tabular}




\begin{tabular}{|c|c|c|c|c|c|}
\hline 15 & $4 / 1 / 14$ & & $7,718.75$ & $(3,250)$ & $4,468.75$ \\
\hline 16 & $5 / 1 / 14$ & & $7,718.75$ & $(3,250)$ & $4,468.75$ \\
\hline 17 & $6 / 1 / 14$ & & $7,718.75$ & $(3,250)$ & $4,468.75$ \\
\hline 18 & $7 / 1 / 14$ & & $7,718.75$ & $(3,250)$ & $4,468.75$ \\
\hline 19 & $8 / 1 / 14$ & & $7,718.75$ & $(3,250)$ & $4,468.75$ \\
\hline 20 & $9 / 1 / 14$ & & $7,718.75$ & $(3,250)$ & $4,468.75$ \\
\hline 21 & $10 / 1 / 14$ & & $7,718.75$ & $(3,250)$ & $4,468.75$ \\
\hline 22 & $11 / 1 / 14$ & & $7,718.75$ & $(3,250)$ & $4,468.75$ \\
\hline 23 & $12 / 1 / 14$ & & $7,718.75$ & $(3,250)$ & $4,468.75$ \\
\hline 24 & $1 / 1 / 15$ & & $7,718.75$ & $(3,250)$ & $4,468.75$ \\
\hline 25 & $2 / 1 / 15$ & & $7,718.75$ & $(3,250)$ & $4,468.75$ \\
\hline 26 & $3 / 1 / 15$ & & $7,718.75$ & $(3,250)$ & $4,468.75$ \\
\hline 27 & 4/1/15 & & $7,718.75$ & $(3,250)$ & $4,468.75$ \\
\hline 28 & $5 / 1 / 15$ & & $7,718.75$ & $(3,250)$ & $4,468.75$ \\
\hline 29 & $6 / 1 / 15$ & & $7,718.75$ & $(3,250)$ & $4,468.75$ \\
\hline 30 & $7 / 1 / 15$ & & $7,718.75$ & $(3,250)$ & $4,468.75$ \\
\hline 31 & $8 / 1 / 15$ & & $7,718.75$ & $(3,250)$ & $4,468.75$ \\
\hline 32 & $9 / 1 / 15$ & & $7,718.75$ & $(3,250)$ & $4,468.75$ \\
\hline 33 & $10 / 1 / 15$ & & $7,718.75$ & $(3,250)$ & $4,468.75$ \\
\hline 34 & $11 / 1 / 15$ & & $7,718.75$ & $(3,250)$ & $4,468.75$ \\
\hline 35 & $12 / 1 / 15$ & & $7,718.75$ & $(3,250)$ & $4,468.75$ \\
\hline 36 & $1 / 1 / 16$ & & $7,718.75$ & $(3,250)$ & $4,468.75$ \\
\hline 37 & 2/1/16 & & $7,718.75$ & $(3,250)$ & $4,468.75$ \\
\hline 38 & $3 / 1 / 16$ & & $7,718.75$ & $(3,250)$ & $4,468.75$ \\
\hline 39 & $4 / 1 / 16$ & & $7,718.75$ & $(3,250)$ & $4,468.75$ \\
\hline 40 & $5 / 1 / 16$ & & $7,718.75$ & $(3,250)$ & $4,468.75$ \\
\hline 41 & $6 / 1 / 16$ & & $7,718.75$ & $(3,250)$ & $4,468.75$ \\
\hline 42 & 7/1/16 & & $7,718.75$ & $(3,250)$ & $4,468.75$ \\
\hline 43 & $8 / 1 / 16$ & & $7,718.75$ & $(3,250)$ & $4,468.75$ \\
\hline 44 & $9 / 1 / 16$ & $(15,437.50)$ & $7,718.75$ & $(3,250)$ & $(10,968.75)$ \\
\hline Total & & & 227,875 & & \\
\hline
\end{tabular}


2. Is the tenant's request comparable to market terms? Should your offer be different from their request?

Answer: Brokers always ask for the moon in an RFP. The case specifically states that the last deals signed at the building have been for $\$ 16.00, \$ 16.50$ and $\$ 16.25$. $\$ 14.25$ is off by $\$ 2.00$. If you want the final lease signed at $\$ 16.50$, then your first offer needs to ask for something north of $\$ 16.50$. Students should model the lease at higher rental rates as well.

3. Do you believe that your offer will be accepted, rejected, or countered by the tenant? Does this alter your answer to question 2 above?

Answer: A counteroffer to your initial proposal will almost assuredly follow. The learning point here is that the final lease will not look anything like your first offer. To convince the tenant that they are creating value for them, the broker will stick to their guns as long as they can with the $\$ 14.25$ rental rate - or at least something substantially lower than the current market rate of $\$ 16.50$. It is ok to say "no" in a negotiation. Your job is to create value for the landlord - not the tenant. Recall that the deal above is not a standalone deal - nor is it mutually exclusive. Another tenant may want the space three months from now. As such, some real estate firms (but not many) use Real Options to value leases rather than traditional Net Present Value. If your course includes Real Options, this case can be very easily extended to use that capital budgeting method as well.

4. Examine the tenant's financial information in Exhibit 1. What gives you pause with regard to their creditworthiness? What gives you a sense of security?

Answer:

Pause: The tenant's broker has only provided you with internally prepared and unaudited financial statements. Unfortunately, this is usually what a tenant will provide you. Audited financial statements are very costly, and tenants' will be reluctant to conduct an audit for purposes of a lease. Occasionally, a tenant will have recently received a bank loan or some other financing that required an audit, and they will make those financial statements and auditor's opinion available to you. You'll have to determine whether or not you think you can trust them. On the surface, the business appears to operate at a loss - mainly due to management compensation.

Sense of Security: Senior Sta-Home has positive retained earnings. This means that they have positive historical profits that have been reinvested into the company. Their current income statement also shows that their last year's rent was $\$ 105,183$. At a rental rate of $\$ 16.50$ for their requested 6,500 
square feet of space, their annual rent payment to you would be $\$ 107,250$ - not a large increase at all. If they've paid their previous landlord on time, they'll most likely pay you on time.

5. Based on your answer to question 4 , what type of security would you require for the deal (security deposit, letter of credit, personal guarantee?)

Answer: To partially cover the upfront tenant improvements, students should initially require two month's rent as a security deposit. If the tenant does not slow pay over the three year term of the lease, the security deposit could be refunded if the tenant were to execute a renewal in 2022 .

\section{WORKS CITED}

Breazeale, J. (2017) Real Estate Investment Decisions I: Commercial Office Property Acquisitions. Journal of Business Strategies 34 (2), 111-124.

\section{BIOGRAPHICAL SKETCH OF AUTHOR}

Dr. Jonathan Breazeale is Associate Professor of Finance at Sam Houston State University - where he teaches Business Finance, Financial Markets and Institutions, and Security Analysis and Portfolio Management. His research interests include real estate, financial education, and working with students interested in publishing research - at both the undergraduate and graduate levels. Prior to becoming a professor, Dr. Breazeale was Vice President of Parkway Properties, Inc. (NYSE: PKY), a public real estate investment trust (REIT) invested in office properties. 